\title{
Transition and Transformation in
} Post-Socialistic Countries of Central and South-East Europe with a Particular View of FR Yugoslavia

\author{
Tomic, P. E Romelic, J.*
}

\begin{abstract}
In this paper first of all at the dinamics of the spatial structures from Europa inside the new political end economical conditons. Then, there were analysed the proces of changing in with the deeping of integration on one hand and the extinction of the European economical space on the other hand are the main decisive factors. The countrises from Central and South-East Europe are in process of regional differentiation both viewing the level of changes the capacities of integration. In this peper is writed a particular view of Serbian and Montenegro.
\end{abstract}

Key words transition, regional development, European Union
* Pavle Tomic, Jovan Romelic, University of Novi Sad, Faculty of Natural Science, Department of Geography, Tourism and Hotel Management, Trg Dositeja Obradovica 3, 21000 Novi Sad, Yugoslavia
$\mathrm{T}$ here is a range of important events in Europe, first of all those in mid-eighties of the $20^{\text {th }}$ century, which will have important influence on direction/course and character of future regional geographic changes, and which are basically described as creating of a so called Continent State.

The first, optimistic view starts from the belief that Europe is too small to be divided. That belief is strengthened by the pulling down of the Berlin Wall, disappearing of the iron curtain and rivalry of confronted systems and models, which brings forward the vision of Europe spreading from the Atlantic to the Ural Mountains (including Russia). An imitation of the USA would be achieved in that way, namely the vision of a Continent State fulfilled, whereas almost all attributes of a state are necessary: strong central authorities, constitution, parliament, ministries, institutions, large number of states (if not all), united market, money, presumably the same language. When all of those factors are obtained, the United States of Europe, counterpart to the USA, Japan, China and India come into existence. At the same time it is the project for peace and prosperity, orderly and continuous development, multicultural, multireligious, multinational, but true omni-democratic surrounding of a legal state, government of law and rights, great social freedom and human rights, unique and recognizable European identity with its system of values.

The European vision is deeply believed and supported by so-called: "Euro-euphorists, Euro- phils, Euromaniacs and Euro-optimists", joined by many citizens in all European countries, especially young citizens. European movements are being created all over the continent.
At present the European Union (EU), an integration of 15 states (over 370 million consumers and purchasing budget of 8.000 billiard dollars, observed individually it is over 22.000 dollars per citizen) is likely to unite, more precisely to accept 13 or 14 states in the future. ${ }^{1}$ Firstly, there are 7 states (the EU has been negotiating with them since 1998), from the Luxemburg group: Estonia, Poland, Slovenia, Czech Republic, Hungary and Cypress. Then 6 states from the Helsinki group: Bulgaria, Romania, Latvia, Lithuania, Slovakia and Malta (the EU has started negotiations in March 2000) will follow. After a dilemma, Turkey has joined the later group (decision made in Stockholm to negotiate with Turkey as a candidate to join the EU, after the requested conditions have been fulfilled). Although there is no formal attitude of the EU, Yugoslavia might be joining the EU.

The process of European unification has assumed a new dimension and raised many questions about perspectives and future of the oldest and at the same time the smallest continent.

Integrating processes and adjustments have included more than half European states (28 out of 47). Many conceptually and practically based issues have been raised in the EU as well as in the countries, which are directly or indirectly, more or less searching for new possibilities.

The later may be applied to all the Republics (now independent states) of former SFR Yugoslavia, which, after the disintegration, tend to join the EU mutually independent and at their own pace. Albania, being one of the Balkan states will join as well.

The states such as Norway and Switzerland would be welcomed as members of the EU, but their popular vote at referendums did not approve the initiative. Approval of the initiative is still uncertain, although some political groups (both in government and opposition) in those countries emphasize the priority to join the EU and pledge for it.

Russia and Ukraine (especially nuclear, energy and natural resources) are of special interest for the EU, and vice versa, but their new position and integrative elements are only speculated about.

The first fundamental base of European economy integration was seen 


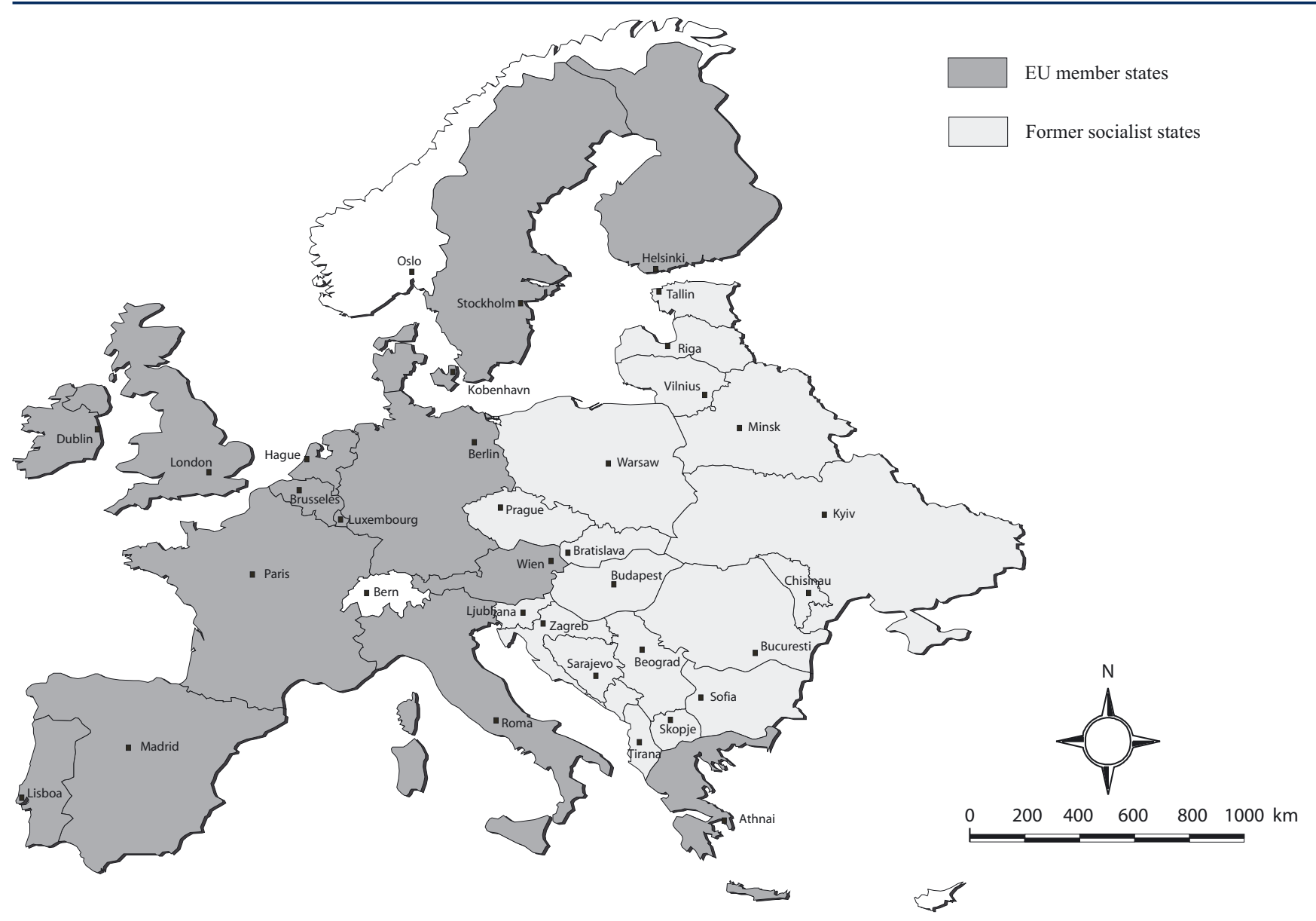

Figure 1 Map or the EU and dynamics of the Continent State creating

through the process of making and consolidation of large economical-political groups, such as European Community (EC), and European Free Trade Association (EFTA). On the other hand, the attempt at realizing the project of continuous making and development of socialistic countries was of short duration, because most of the countries switched to economic policy, which supports legitimate and free market economy. Consequently, the second phenomenon had appearance and strengthening of new national movements, and as a final result forming of new European states.

The beginning of more decisive, radical integrations in Europe, has been labeled by efforts to find the most constructive solutions to prevent declining trends of economic power in traditionally industrial regions, and later to constitute and support new industrial entities. As a part of these, a new relationship has emerged towards, borderline, peripheral regions, which were structurally weak and neglected, whereas development of socio-political and administrative centers has strengthened simultaneously. In 1990-s, there was not only a search for solutions in new and prosperous regional and states integrations, but also in finding new models of transition for post-socialistic countries.

Post-socialistic countries predetermine the challenge of solving the problem of multilevel transformation in politics, economy, and society. In that way, they face a dilemma. Firstly, they are obliged to undergo a complex transformational process, which has to be under constant analysis. Occasionally, certain measures referring to economic aspects of system strategy have to be corrected or even reduced. Thus, these countries have to try persistently to compromise with the standards of development, prescribed by the EU.

\section{Transformation and its Effect on Geography}

The survey of regional-geographic literature, which refers to transformational research in the field of politics and economy, has confirmed that theoretical assumptions, terminology etc., have been examined in detail by two authors. ${ }^{2}$

Förster (1998), emphasized that while observing the process of transformation in post-socialistic countries, it is necessary to follow three dimensions:

1. System dimension - understood as the mode and nature of the changes in social and economic system.
2. Time dimension represents all historical circumstances under which the system transformation is performed.

3. Regional dimension - reveals the influence and effects of the transformational process upon the actual geographic entirety. ${ }^{3}$

Gloter (2000), proceeds from the analysis of negative aspects of socialistic economy: industrial domination, state's property, inconvertibility, state's prices, and insufficiencies of budget restrictions.

With entering the system transformation, the following processes and effects should occur:

1. Institutional innovations (privatization), competitive policy, and membership in international associations.

2. Newly defined state's roles (the state as the creator of economic physiognomy of borderline regions) and new tasks of economic policy (social policy, and policy of economic growth and development).

3. Macro-economic stability (budget consolidation, stable politics, treasury policy, and monetary policy)

4. Structural transformation (economy structure, foreign trade intensity, di- 


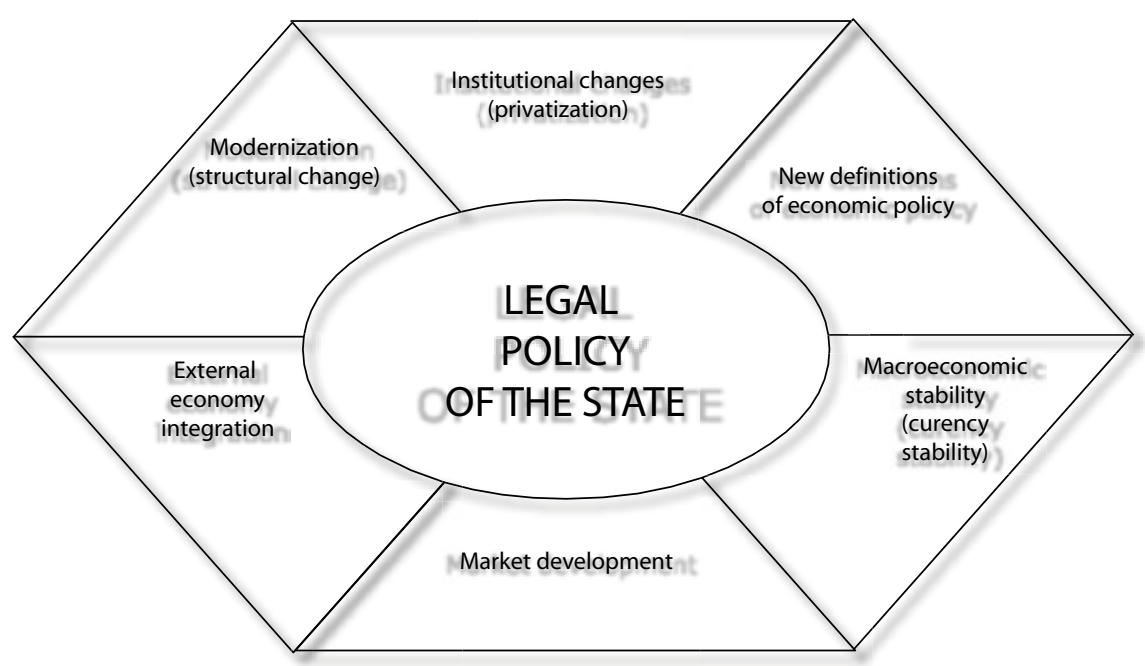

- Figure 2 Model of system transformation for countries in transition, Förster (1998)

rect investments intensity and trade technology).

Transformational processes of different quality and quantity are performed within the existing regional categories:

- urban-industrial sites (socio-political and administrative centers)

old industrial regions,

- peripheral regions (borderline regions)

in dispersion

Ability of a certain region in solving transformational problems, depends on three groups of factors, as a rule:

- economic branches and activities, i.e. economic structure

- regional-economic development

- dispersion of economic centers and their ability to accept capital, investments and modern technology, quickly and efficiently.

The whole transformational process in post-socialistic countries is done under conditions of European regionalstructural model. Its constituent parts are "development axes" and "development regions or zones" (Entwicklungraum). Thus, in the European Union by the end of 1980s, north-south development axis was segregated, following the line drawn from the Rhine River, the Rhone River and to Lombardy. It was known by the name "blue banana". The second axis was of double regional character, covering the area from Toscana to Mainland and from Lion to Barcelona and Valencia (European sea belt). But the unification of Germanys and opening of post-socialistic coun- tries will cause this European regional sample to be modified. Gorszelak (1997), who formed so-called CentralEast modification of regional structure by adding the former socialistic parties of Central and East Europe, did the same.

\section{Regional Economical-geographical Processes and Changes in Post- socialistic Countries}

In almost all newly designed concepts of transformational process, internal and especially international regionalization of post-socialistic countries should be performed, although most of the authors emphasize the fact that it is not the final result planned by structural and regional policy of European Union. Taking into account "economic development", "macro-economic stability)", and "progress in development", which are defined in 1992/1995 agreements, clear differences between the countries of Central-East and SouthEast Europe were established.

Relating upon the mentioned parameters, evident succession of countries (Slovenia, Czech Republic, Hungary, Poland, Estonia, etc.) in gross national product is perceived. In direct foreign investments, the first position is occupied by Poland, then Hungary and Czech Republic, whereas other countries follow slowly. Special economic and structural problem in those countries is the gross national product per capita, which is $25-50 \%$ of average in

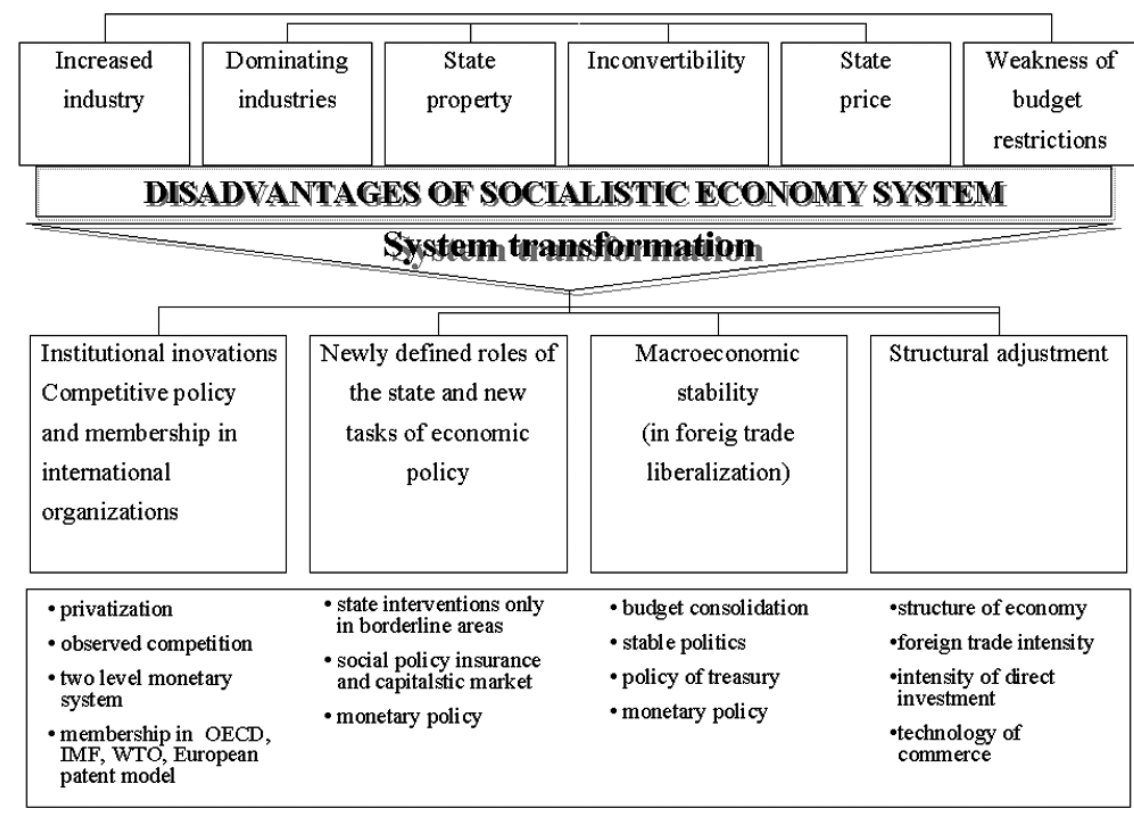

- Figure 3 Model of system transformation in post-socialistic countries (Glühter 2000)

Table 1 Transformational model of economy of countries in transition

\begin{tabular}{|c|c|c|}
\hline First phase & Second phase & Third phase \\
\hline "Small" privatization of services & $\begin{array}{c}\text { "Medium" privatization (food } \\
\text { industry, civil engineering, etc) }\end{array}$ & $\begin{array}{c}\text { "Large" privatization (basic industry, and } \\
\text { electro-energetic system) }\end{array}$ \\
\hline
\end{tabular}

the EU countries. There is also an inadequate percentage of employees.

The process of regionalization, as a result of transformation becomes obvious, if represented in the form of model consisting of three phases of privatization process and effects based upon transition of ex-socialistic countries through those phases.

Regionalization of private businesses in Czech Republic points out the priority, i.e. advantages of metropolitan regions. Thus, about $1 / 5$ of private businesses is concentrated here, that is to say $1 / 3$ of trade associations. The similar situation has been proved by the researches conducted in other post-socialistic countries of central Europe. 


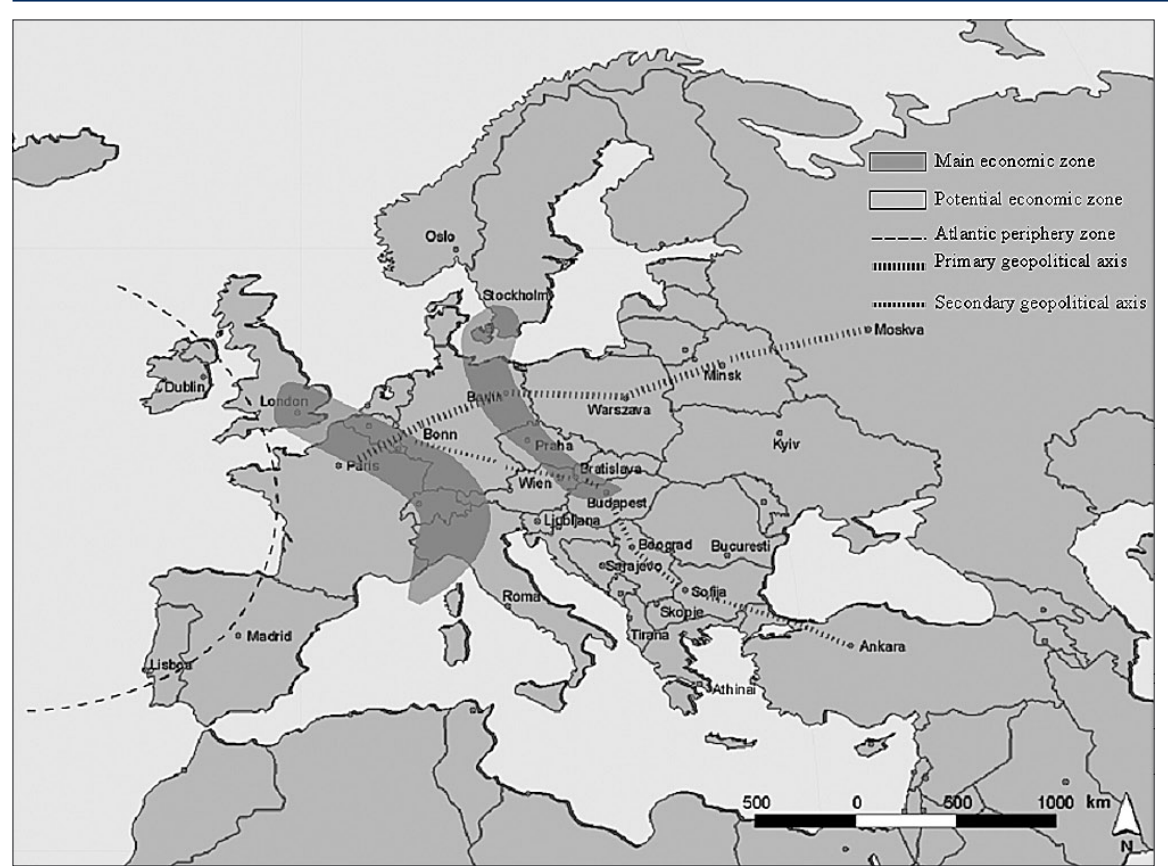

- Figure 4 - Axes of EU development

The intensity of transformational process, which reflects in some regional changes, has been analyzed in Hungary. According to the amount of influx of foreign capital and unemployment as indicators of circumstances in regional-economic structure, the following opposed features are noticeable: Budapest as a metropolitan city is situated in trans-north-Danube and south Hungarian region, and the very position of the city with big concentration of capital shows the advantages of the region it belongs to as well as disadvantages of east and north-east parts of the country.

As estimated according to Kaufman and Menke (1997), about 40 billions of dollars has been sent to northeast and southeast Europe by the year 1996. $90 \%$ from the total investments is in countries, which are members of EFTA. The differences among certain post-socialistic countries are clearly seen: Hungary has received $40 \%$ of the total, Poland 23\% and Czech Republic $16 \%$. Assuming those data, it is possible to expect certain financial package for Yugoslavia. Its realization has already started with the various EU and USA donations, after the donor conference in 2001 and writing off the substantial part of the national debt by the Paris Club. The amount of money is highly unpredictable to be discussed at the moment, but certainly it will be conditioned on speed and quality of changes in our country, which are to be discussed in the second part of the paper.
Within the countries themselves, socio-political and administrative centers dominate in investments obtained. In that way, Budapest received more then one third of the total foreign investments in Hungary between 1990 and 1994, the same occurred with Prague in Czech Republic. In Poland and Romania, the share in investments for the capitals, Warsaw and Bucharest was even higher. Spatial distribution of direct foreign investments has clearly shown which and what quality indicators should an appropriately positioned region posses, that is to say what characteristics should predetermined regional policy have. Certain regions, having advantages of external economy (infrastructure, concentration of potential employees, scientific research centers, etc.), become very attractive, whereas contractive abilities Socialistic Countries of other parts of the industrial area become restricted.

A similar, well-incorporated model is seen in the example of Czech Republic (polarization from the center to periphery), then Poland (polarization from the center to periphery too, but also some opposing trends in the west and east of Poland, or even in the example of Romania (center and periphery, opposition between the west and east Romania).

Our country, despite all unfavourable conditions caused by delayed transitional process, has an opportunity to choose the best model from the previous examples and avoid the already made mistakes. It seems very important that at the very beginning of the process of transition, our country has already had regionalization (omnibus law for Vojvodina, Law of local selfgovernment as well as other laws following the regionalization). It is almost certainly obvious, that over-investing in big cities, Belgrade, Novi Sad and Nis should be avoided, since Budapest, Prague, and etc. have already had many problems difficult to solve, from which some should be mentioned: protection of the environment, infrastructure, shortage of permanent housing, social protection, education and etc.

Post-war prevailance of the soviet model in economy and society in some socialistic countries meant intensification of the principle of economic sectors, which is opposite to more qualitative and valuable regional principle. In the soviet system, "iron concept" existed, which included strong heavy industry on one side as well as the principle of "turning the national industry into chemical". It was the base pillar of

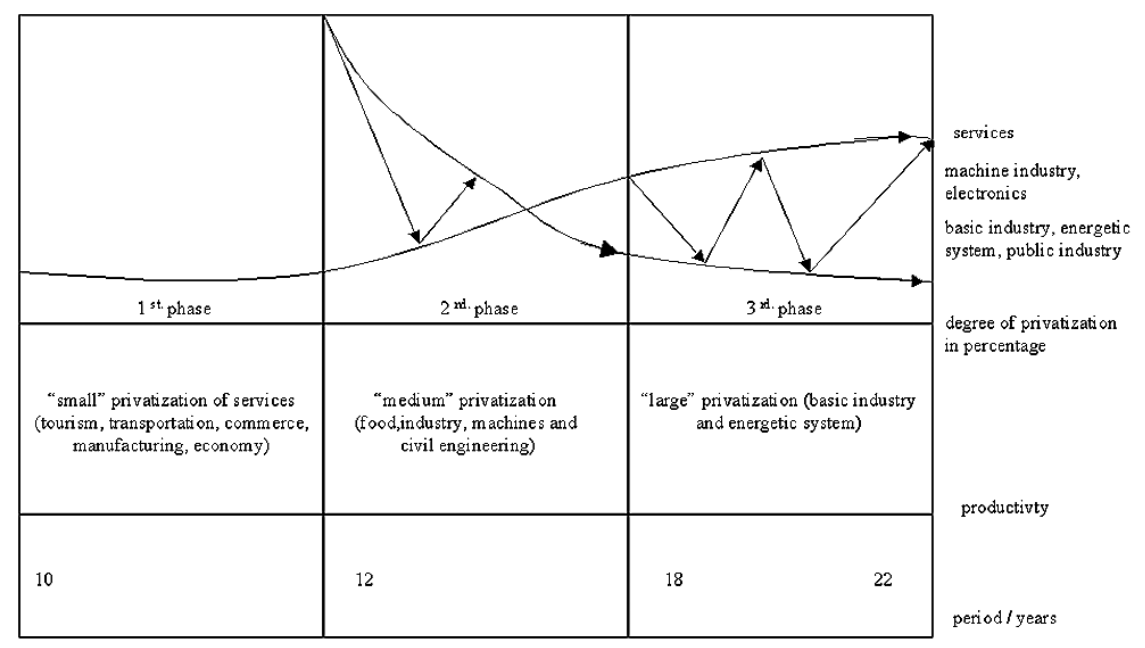

Figure 5 Model of Phased Regional, Economic and Geographic Changes in Post- 
economic and structural policy in those countries. It resulted in forming large industrial complexes, which basically represent rather slow and fixed spatial category, reluctant to transformations, or structural changes. This type of problem has been recently solved by Czech Republic by the process of privatization of elementary industry. Out of 100 industrial companies in the country, more than half belongs to the state $(18 \%$ are of energy and $15 \%$ of chemistry branch). The old industrial regions are situated in the north of Czech Republic, and the south of Moravia, around Plzen in the west of Czech Republic. Also a big problem is the north region where black coal is exploited. Probably there is no other region in Europe, which has rearranged physical-geographical base, i.e. former cultural district by its industrial activity, as is the case with the Ore Mountains in Czech Republic. There are 6-7 billion of tons of black coal, between the Ore Mountains and the Bohemian-Moravian Highlands, sufficient for 100 years of mining, which was developed on densely populated industrial districts of former Czechoslovakia. Coal mining, refined coal, energy, metal industry, and chemical industry were predetermined industries for this region because of the raw materials and because of their interdependence. The formerly used excavations of shaft type, and later daily excavations were obstacles for planned changes in transport and settlements. Thus, the mentioned regions represented powerful and important center in the high phase of socialistic development. Nowadays, those regions represent $20 \%$ of total energetic supplies and around $40 \%$ of total energetic capacity in Czech Republic.

The development of industry in former Yugoslavia has partly followed this model, with the additional problem of planned localities, "key" selection for equal distribution of vital industrial objects in the republics and provinces. After former Yugoslavia fell apart, most of those objects encountered insuperable difficulties, caused firstly by the loss of market and secondly by sanctions imposed to our country. First of all, those objects were Car Industry "Zastava" in Kragujevac, Metal Industry in Belgrade and etc.

The policy of transformational economy in Czech Republic should have initiated certain measures in four major state's industrial regions with 23.000 employees and production of around 60 million tons of final products. In 1998, privatization started and disturbed the principle of granted employment of the former system, which resulted in economic and social conflicts.

Contrary to the old industrial region in the north of Czech Republic, Moravian Region_solved its structural problems rather quickly but not always successfully.

In mid 1980 s, $87 \%$ of hard coal (23 million of tons), $78 \%$ of coke (8 million tons), $65 \%$ of pig iron (7 million tons) and $59 \%$ of steel ( 9 million tons) were produced in industrial region of Ostrava as compared to the country's production. When transformational processes started, the number of employees was significantly reduced. Organization of production was rationalized and the structure of economy changed. Those are evident indicators of structural adjustments of existing regions according to new trends, and new changes concerning industrial development in higher phases of production, development of services and intensified role in international cooperation are expected.

Similarly, but in higher proportion, the Upper Silesia region, of great importance for the whole Europe, was lost. Nowadays, this region is a very big transformational problem. Its population is 3,9 million, and its area $6.650 \mathrm{sq} \mathrm{km}$. The Upper Silesia has $15 \%$ of the total industrial production and it is at the same time densely populated, the biggest industrial region in Poland. Formerly, it developed in the narrow borderline area, and produced about 70 billion tons of coal supplies. Later, during the $19^{\text {th }}$ century, building of furnaces, coke factories and metal industry plants broadened the area. In its history the region belonged to different political and territorial districts. Demand of fast rebuilding of Polish industry after 1945 and the application of the "soviet concept" not only failed to preserve inherited structural features, but also left long-term negative ecological and geographical consequences. However, transformation of Polish economy, nowadays more frequently defined as the way towards "strong" state of Poland, has succeeded after the initial failure. Drastic decline of mining (reduction of coal production from 188,6 million tons in 1985 to 129,8 million tons in 1994) was caused by structural changes (increase of services) and advanced privatization (60\% of the total economy in 1993).

Similar process of structural adjustments with far less success was characteristic of old industrial regions in Hungary (Pesc and Miskolc) and Romania (Resita). That is where restructuring of unilateral orientation of dense urbanindustrial regions was also undertaken, but the estimations of the procedures were often problematic. However, it is possible to conclude that the present development of the area and transformational movements have resulted in certain changes, which are deprived of negative connotations, and have the usual form of structural adjustment.

In the state's sector, new type of reprivatization appeared, that is to say, privatization in agriculture, capable of competition with modern agriculture within the future economic development as a whole.

Regional example of disorderly and inadequate transformational process is characteristic of Romania. Namely, foreign investments and transformational steps were conducted to certain extent, so that they were opposite to the general attitude of the European Union. Therefrom, similarly to Poland, high percentage of employment in state's industry and miniscule production indicate enormous problems on its way to join the European Union.

Taking into account the mentioned selection, "key" model and existence of small number of those gigantic factories, we consider that Yugoslavia is capable of performing structural changes of its economy more easily. To support the statement, we have in mind, first, extraordinary position of civil engineering, food industry and energetic system, good position of metal industry, shoe industry and rather unstable position of heavy industry, ferrous metal industry and transportation.

\section{FR Yugoslavia on its Way to Joining the European Union}

In contrast to those mentioned countries, Federal Republic Yugoslavia has distanced from the EU from year to year, since its formation. The reasons why and in what way are quite familiar to us. There is a long list of misfortunes, left by the former regime ranging from undefined constitutional-legal disorder, bankrupt economy, to social poverty, wars, collapse of banking system and 
many other that are not to be mentioned here.

Nowadays, most of the political problems in relationship between FR Yugoslavia and the EU are neutralized. The counties members of the EU and the EU as a unity have supported all phases of democratic changes in our country. Without exaggeration, it is possible to say that greatly thanks to that support, quick and, what is also important, "painless" political consolidation was performed in the country. FR Yugoslavia was reintegrated in international associations; our membership in important international organizations was regained. Engagement and help of the EU during that period were precious. However, there was the support of other important international factors.

Taking into account experience of the other countries in central and Eastern Europe, it is possible to say that all the countries went through different phases, and generalization is hard to be made. An important factor in the early phase of transition is to provide macro economic stability, followed by economic stability on micro level. The fact is presently happening in Yugoslavia, the exporters do not export, despite the stability of dinar, which is one of the conditions for economic development. Yugoslavia has had tradition, when export is in question, but the tradition has been degraded or partly disappeared in the last ten years, and the process for its revitalization is necessary. What is good in Yugoslavia is the existence of more developed part of private business than in other countries in transition. No matter what the problems in the past were, small enterprises succeeded in obtaining funds and well-trained employees - people in Yugoslavia are educated and capable, what was confirmed in detailed research conducted by the EU. Another important step was the readiness of Yugoslav government and foreign banks to ensure loans for small businesses. Further important issue is formation of the EU center, which will enable the companies from the EU to contact Yugoslav companies directly. However, it is important to emphasize that there is a rather serious problem, stopping the foreign investments at present. The problem is perceived in legal regulations and obscure vision of Yugoslavia, as a politically unstable country. Foreign investors want not only essential security for their investments, which will be law- regulated, but also market stability, corruption exclusion, order, work, discipline, transparency and etc. Formation of such a society and a surrounding is the first feature to be realized, which also demands hard work, especially in the starting phase of transition, in order to obtain great number of foreign investors. This opportunity will be used to emphasize the indispensability of the EU idea to form Association of foreign investors. The same was performed by Baltic States for example. The most important European businesspeople would assemble in the association and define ways to help the government improve laws and environment, in order to enlarge number of investments. It is significant to highlight that those countries, which made strong connection between local (national) economic subjects, government and foreign investors, actually succeeded in improving their economic position in Europe.

Finally, it is necessary to emphasize the misleading opinion that for joining the EU, it is enough to change legal regulations and thus make progress towards the goal. However, passing the laws is not satisfactory, their practical application in all structures of society is essential. The EU directors in the environment preservation branch are very strict on this subject, and demand large and visible changes, investments and etc.

Certainly, the key question arises, which is defining the approximate date of joining our country to the EU. Numerous unknown issues, difficulties and obstacles interweave the question. It is our opinion that, at present three possible years: 2015, 2010 and 2007 are in question. The last one seems to be the most optimistic, indicated by Serbian government. It is based upon the reforms done in 2001 and 2002, large support and even admiration of international community for the obtained results, and also growing support of our citizens.

\section{Conclusion}

Our country is entering the process 10 years late, but it has possibilities to go through the process approximately three times faster than former socialistic countries of central and eastern Europe, which also means that there is a real opportunity to become the
EU member already in 2006. Regional integration on one hand and transformation, i.e. broadening of European industrial area on the other were and still are important factors. Frequent discussions about the future structure and role of Europe are between "Agenda 2000" and decisions of European top from Luxemburg. The broadening of the EU is of historical significance for the member countries as well as for applicant countries. For post-socialistic countries, the concept of "broadening towards east" is the basis for changes. In the last years, the Eastern bloc fell apart into independent integration regions, where EFTA, the model of cooperation in the process of integration, showed its significance. In all the EU explanations, discussions, expenses, income and possibilities of "broadening towards east", the fact that countries of former Eastern bloc entered the process of transformation with great hope in prosperous development and relying on the EU general support should not be neglected. Sooner or later, the fact that the post-socialistic countries have reached the criteria of the process of integration should be accepted.

\section{References}

To summarize, The European Union - EU has evolved (since 1950) as a supranational organization of 15 countries (formerly 6, 9, 10, and 12), dedicated to increasing economic integration.

The member states (Germany, France, Great Britain, Italy, Spain, Netherlands, Belgium, Greece, Portugal, Austria, Sweden, Denmark, Finland, Ireland, and Luxembourg) gradually formed supranational institutions and administration, forming the legal frame and supranational policy.

In concordance with the proclaimed aims and its potentials as the whole, with higher or lower influence of member states (primarily the largest), the EU is trying to increase homogeneity and integrity as the means of achieving interests in international economy. The biggest achievement was Economic Monetary Union (EMU) and the currency Euro, launched on January 12002.

The EMU consists of 12 EU members, actually all except Great Britain, Sweden and Denmark, whose decision of joining the Euro zone 
was postponed, and thus their participation in monetary institutions and bodies restricted.

The chairman of the EU is selected for the period of six months, as the first among the equal. All the countries are attributed the right to be chosen, regardless their economic power or population size.

Owing to the rotary principle, The Grand Duchy of Luxembourg as the smallest country in the EU (population of 427,000, gross national product of 42,298 US\$ per capita), Germany as the leading country in almost all aspects (population of 82 million, gross national product of 29,542 US\$ per capita) and Belgium, state of the medium size and economy (popula- tion of 10 million, gross national product of 25,586 US\$) have the right to launch initiatives, suggest and decide on principles, and represent the EU by being hosts to the most important meetings.

In order to preserve the continuity in European affairs, Trio of Representatives is formed (the minister from the EU chairman country, the minister from the last chairman country and the minister from the next chairman country).

In 2002, Belgium, Spain and Denmark will lead the evolving continuity of European affairs; From January 1, 2002 to June 30, 2002 the chairman was Spain. As a rule, the chairman country tends to launch the issues it is greatly interested in, achieve suitable solutions and partly realize its interests.

2 Förster, H (1998): Transformation und Regionaletwicklungsprozesse in Ostmittel und SüdEuropa, Proceedings of the Regional Conference of Geography "Danube-Cris-Mures-Tisa Euroregion - geoeconomical space of sustainable development", West University of Timisoara, University of Novi Sad, "Jozsef Atilla" Univeristy of Szged, University of Tübungen, pgs 391398

3 Glöter, H. (2000): RäumlicheAspekte von Transforamtionsproblem aus systematisher Perspektive, Europa-Regional, Institut für Länderkunde, Leipzig, pgs 35-51 